\title{
Correction: Greater aortic inflammation and calcification in abdominal aortic aneurysmal disease than atherosclerosis: a prospective matched cohort study
}

Joshi NV, Elkhawad M, Forsythe RO, et al. Greater aortic inflammation and calcification in abdominal aortic aneurysmal disease than atherosclerosis: a prospective matched cohort study. Open Heart 2020;7:e001141. doi: 10.1136/openhrt-2019-001141.

Author name Jonathan Boyle has been updated to Jonathan R Boyle.

Open access This is an open access article distributed in accordance with the Creative Commons Attribution 4.0 Unported (CC BY 4.0) license, which permits others to copy, redistribute, remix, transform and build upon this work for any purpose, provided the original work is properly cited, a link to the licence is given, and indication of whether changes were made. See: https:// creativecommons.org/licenses/by/4.0/.

C Author(s) (or their employer(s)) 2020. Re-use permitted under CC BY. Published by BMJ.

Open Heart 2020;7:e001141corr1. doi:10.1136/openhrt-2019-001141corr1

A) Check for updates 